\title{
The Humanitarian Impacts on Internal Conflicts in Indonesia: A National Security Analysis
}

\author{
*Denik Iswardani, \\ **Sharifah Shahirah Syed Sheikh \\ *Political and Social Science Faculty \\ University of Budi Luhur \\ Jakarta, Indonesia \\ **Faculty of Administrative Science \& Policy Studies \\ Universiti Teknologi MARA \\ Shah Alam, Malaysia \\ *denik.iswardani@budiluhur.ac.id
}

\begin{abstract}
Internal conflicts which frequently occur in some parts of Indonesia such as Aceh, Maluku, Poso and Papua have caused many casualties and losses. If it continues, this situation will threaten the regional security. This article explains the impact of the humanitarian problems as a result of internal conflicts in Indonesia by analysing the national security concept. By using secondary data obtained from literature review and observations in conflict areas, this study depicts that the internal conflicts that occur has led to insecurity of society, which could threaten for nation's stability. The study concludes that
\end{abstract}

ISSN 1675-1302

(C) 2014 Centre for Media and Information Warfare Studies, Faculty of Communication and Media Studies, UiTM 
the government's inability to guarantee the security of the entire country could threaten national security.

Keywords: Internal Conflicts, National Security, Security Threat

\section{Introduction}

As an archipelagic state, the Republic of Indonesia consists thousands of small and large islands with resources scattered throughout the country. The population exceeds 200 million and is very diverse both in terms of ethnicity, religion, language, custom and race. With such a society, on the one hand, it can be considered as an asset, but on the other hand it has the potential to disintegrate. After the resignation of President Soeharto in 1998, the internal conflicts are increasingly widespread in Indonesia. Vertical conflicts between local and central government - and horizontal conflicts - conflicts between different ethnic - group that occur in some areas in Indonesia arise in various forms, such as protests, statements, discourses, frontally attacking each other, giving rise to demands for independence or separatism. This kind of social conflicts is very vulnerable considering the country that consists of thousands of islands and the size diverse primordial identities.

Humanitarian impact is a term used in discourse related to the consequences of natural disasters or weapons of mass destruction, i.e nuclear weapon to human life. United Nations Office of the Coordination of Humanitarian Affairs (2009) used this term in climate change discussion. In terms of the weapon mass of destruction, Europe Integration Foreign Affairs, Federal Ministry Republic of Austria (2014) is organizing a Vienna Conference on the Humanitarian Impact of Nuclear Weapons on 8-9 December 2014. Meanwhile, the concept of national security is related to measures taken by national leaders in protecting national interest and power. National interest and power need to be safeguarded in order to ensure that citizens are able to receive their basic needs, rights, justice and order. After the Cold War era, the concept of security is more multi-faceted and complex. National security also encompasses regional security, societal security, human security as well as environmental security [1][2]. 
The following section discusses the impact of humanitarian problems that arise due to a number of conflicts that occur in some areas in Indonesia, especially in Ambon (Maluku), Poso (Central Sulawesi), Aceh and Papua. The impact of humanitarian problems is analyzed in the context of national security threats. The case in Ambon and Poso is an example of horizontal conflict. This communal conflict has escalated into a major conflict that could threaten national security. While the conflicts in Aceh and Papua is a vertical conflict that actually is a threat to the stability of Indonesia's national security [3][4].

\section{Humanitarian Impact of Internal Conflicts in Indonesia}

The conflict in Maluku that occurred between 1999 until 2002 originated from a dispute between two young men, and later evolved into communal riots. Then, this conflict became a religious issue between the Islamic and Christian groups. Then, the unrest also extends to the issue of anti-Buton Bugis Makassar (BBM) and began to spread throughout the Moluccas such as Aru, Kei, North Maluku, Corella, Buru and even spread as far away as the island of Lombok [5]. Communal conflict in Poso was also preceded by unrest in the community. Ethnic and religious diversity has become a sensitive issue. The conflict raged when there is emerging distrust of the security forces, especially the police. Although communal conflicts has been declared over, but the security situation in former conflict areas are still not fully stable. So there are frequent acts of violence to provoke a riot that still happen.

On the other hand, vertical conflicts in Aceh and Papua is caused by local dissatisfaction with the central government. The rebellion in Aceh was first stated by Muhammad Hasan di Tiro, who declared independence of Aceh on December 4, 1976. In 1989 the Free Aceh Movement (GAM) did the rebellion, then the government responded by declaring Aceh Military Operation Area (DOM) [6]. After several negotiations, Aceh finally reached a peace agreement. However, peace that has been envisioned by all parties was often disturbed by the occurrence of several security problems. The vertical conflict that is still ongoing is in Papua. Armed insurgency as increasingly apparent as the Free Papua Movement (OPM) was officially established in 1964. Then, on 4 
April 1965 the State of Papua declared in Manokwari, and began an armed revolt led by John Ariks and continued by Mandatjan \& Awon brothers [7]. Until today, the armed contacts with the security forces are still on-going. The internal conflict in Indonesia has caused a lot of casualties, both property and lives. In general, the civilian population is the most severely affected by the conflict. Many had died and suffered injuries, and they were even forced to be displaced because of the increasing escalation of conflict.

\section{i. Deaths and Injuries}

Although there are no valid data on the number of victims of the conflicts in some areas, but the number of deaths and injuries is quite alarming. Wilson (2005) [8] examines the domestic conflict in Indonesia stated that $75 \%$ of the deaths were caused by collective violence, in which $18 \%$ of them are victims of the conflict in Maluku. Regarding the number of victims of the conflict in Maluku itself, there are some differences in the data. Based on the police chief reports to the House of Representatives (DPR) June 3, 2002, the death from the Maluku conflict of 1999-2002 amounted to 1,842 people [9]. But, the ICG noted that the death toll in Maluku was more than 3,500 people. While Alhadar (2000) and Dodd (2000) found approximately 40\% of victims, or about 4,000 people died in North Maluku; 40\% in Central Maluku (Seram, Ambon and Lease Islands); and 20\% died in Southeast Maluku especially in Banda, Aru and Kei Island [10][11].

The number of the people who died in Poso has reached thousands. An estimated 960 people were killed and about 2,000 were declared missing and hundreds of others suffer lifelong disability [12]. The victims continue to grow although the conflict in Poso is over and stability has been maintained. Based on the KONTRAS record, between October 2006 and January 2007 as many as 79 people died by gunshot wounds, and 207 people were injured by firearms. They became victims of security forces or due to misuse of firearms by civilians [13]. Conflict in Aceh has also killed thousands of people. Just within one year after the implementation of martial law, the military claimed they have killed 2,000 members of GAM [14]. 
An estimated 10,000 people have died since the rebellion in Aceh in 1980 [15]. Victims continue to grow despite the martial law being lifted in August 1998. Until the end of 1999 an estimated 447 people were killed and 144 others missing [16]. A year after the memorandum of peaceful understanding, 14 people were killed [13]. While in Papua, several policemen and civilians were killed as victims in armed attacks that often occur. During the conduct of military operations in Papua, in the era of the New Order regime, at least 100 thousand indigenous people were killed. Target killings were not only against OPM leaders, but, also against Papuans that were regarded as OPM strongholds. Until now, the case of shootings of security forces and civilians are still common. Attacks are carried out by armed groups using the most modern weapons [3].

\section{ii. Violence in the Community}

Besides killing and injuring civilians and security forces, conflicts that raged also has fuelled violence in the society. The forms of violence that often occur are vandalism, burning and blasting the buildings both of civil residents and public buildings. Violence is the citizen's way to express their feelings. In Poso for example, according to Poso Center between the years 2005-2006 occurred 60 cases of violence occurred in the city of Palu (Suara Pembaruan, January 2, 2007). Some 16.474 homes were damaged throughout the conflict [17]. The conflict has also destroyed the houses of worship, government offices, stores and shopping centers. In Central Sulawesi, until December 200160 schools have also been destroyed by the conflict [15].

In Maluku, the destruction of opposed group's homes being the main target for communal conflict took place. Malukus conflict has destroyed 41,000 homes, 23,300 of which are homes in North Maluku [18]. School buildings were also targets of conflict cruelty. For example, 5 Tadika, 100 elementary schools, and 34 junior high schools were destroyed throughout the conflict occurs [20]. Campus of UKIM (Indonesian Christian University in the Moluccas), Unpatti (Pattimura University) and Polytechnic of Unpatti have also been destroyed by the supporters of the Muslim group, Laskar Jihad. Meanwhile Antara, May 172000 reported that in Aceh, in January 
2004 more than 70,000 students could not attend their schools because the school buildings were damaged. The most affected areas due to the impact of the conflict are the villages in Pidie and Bireun. After a memorandum of understanding peace has signed, criminal cases in Aceh increased dramatically until $372 \%$. Police recorded the total robbery cases reached 49 .

In Papua, armed violence between the military forces with OPM raises fear and insecurity in society. Rebel group violence has always dealt with firmly rebel groups by security forces, causing unrest that plague the society. For example, over the past four years, at least 74 people have died in the village of Baad alone - one of more than 160 across Merauke- due to infighting between communities created by disagreements over the sale of land to agribusinesses, and police brutality, according to Leonardus Maklew, a Baad resident who has been representing nine Malind villages in negotiations to defend their land from an Indonesian sugar cane plantation since 2010 [21].

\section{iii. Domestic Refugees}

Internal conflicts in Indonesia also have forced people living in conflict areas to become refugees. Most residents who were forced to flee out of the conflict areas are migrants who are not native to that area. In Maluku for example, due to the issue of anti-BBM, many native residents left the Moluccas. Approximately 860 thousand inhabitants have left the Moluccas, where 280 thousand people live in refugee camps in the South Moluccas and about 78 thousand people living in North Maluku [22]. North Sulawesi, the main purpose of refugees who are Christians, while Muslims who were mostly migrants Bugis from Makassar, trying to return to their homeland to the South and Southeast Sulawesi. Antara, May 172000 reported that there are at least 107 thousand Butanese and about $22 \%$ are refugees. Upon the arrival of Laskar Jihad, a wave of Christian refugees is increasingly widespread. Meanwhile, Kompas, July 31, 2000 reported that there are between 1800030000 refugees who have returned to their country of origin namely West Papua, and approximately 4,000 to Nusa Tenggara Timur. Until the final quarter of 2005 as many as 15788 people have become IDPs (internally displaced persons / IDPs) where 14,438 are still in the Moluccas and 1,350 were outside the Moluccas [9]. 
Similarly in Papua, the presence of migrants from outside the island through transmigration program has led to the existence of economic jealousy because most of the newcomers have a better economic situation. In addition, they are also more hard working. In conflict situations, migrants are often targets of attack Papua's militants. But many indigenous people were also forced to become refugees. Due to security operations carried out by military / police to search for the unrest, many residents out of fear chose to run and live in the forests or other safer areas. Even referring to Crescent International, there are about a thousand refugees from Papua who are in Papua New Guinea and asked to go back to Papua. Moreover, Poso conflict refugees are still very reluctant to return to Poso because they lack of trust of the government, until now there are around 2,000 refugees still living outside the town of Poso. They are found in North Sulawesi, South Sulawesi, and partly in Java. Currently 33,000 refugees are already in Poso but not back to where they came from [23]. They fled to areas where most of the people are of the same religion. Muslim population chose to flee to Dongala, Palu, Gorontalo (North Sulawesi) and South Sulawesi. While, the Christian population fled to Tentena, North Lore, Tanah Toraja (South Sulawesi), Manado and Minahasa (North Sulawesi). The refugee division has led religious sentiment to grow even stronger. That impression will widespread the conflict [24].

The number of Aceh transmigrants who fled to other areas when the conflict occur reached 21270 households, or over half of transmigrants in Aceh. They were afraid that miseries of conflicts could occur again and again at any time in the future. Their fear is quite reasonable since Aceh has a long conflict history [25]. Although not all immigrants are getting the help they need, but at least there were hopes for residents of Aceh after the MOU of peace was signed. Acehnese who fled from battle field now feel safe to go back to other regions in Indonesia, Malaysia, Europe and the United States [26]. The occurrence of internal conflicts that led to a humanitarian crisis shows that there is an entity that threatened them. Indonesia's national security concept used in this study refers to the notion that the state's ability to protect against all types of threats both from abroad and domestic, and for the welfare of all existing entities. Therefore, national security includes the individual security, public safety and homeland security. The ability of a country to control and 
keep peace in the region will ensure national security. Indonesia's national security is also formulated to pursue core values that is "to protect the people of Indonesia and the country of Indonesia" as stated in the preamble of the Constitution of the Republic of Indonesia.

Humanitarian impact of conflict such as the number of civilians injured or died showed that their security is threatened. The security of individuals and communities is threatened when they are unable to perform their daily activities safely during conflicts. Residents cannot earn a living for the sake of their survival, children can't attend school because their school buildings were destroyed, they can't worship in peace, even many of them were forced to leave their homes and become refugees. This situation also proves that people who lived in conflict areas are not prosperous. Disturbance and security threat as well as the lack of public amenities can eventually destabilize the national security.

\section{Conclusion}

Based on the discussion above, this paper concludes that a government's inability to maintain the security of the entire entity will ultimately threatens the national security. The civil society's distrust of the security guarantee makes some of them seek their own security. This shows that the government is not able to guarantee their safety. The feeling that they are all victims of conflict can provoke resentment and if there is a chance they will be avenged by the violence as well. Internal conflicts will continue. This means that the national security threat will continue if the problem is not resolved.

\section{References (Including Missing Citation-Ref)}

[1] B. Buzan, (1981). People, States and Fear: An Agenda for International Security Studies in the Post-Cold War Era. Hertfordshire: Harvester Wheatsheaf.

[2] M. Stone, (2009). Security According to Buzan: A Comprehensive Security Analysis? Paris: Security Discussion Papers Series 1. 
[3] Human Rights Watch. (2001). Catatan kondisi hak asasi manusia Papua 13 (2). Jayapura: Lembaga Studi dan Advokasi Masyarakat.

[4] Global Security. (2000). Military: Maluku. (online). http://www. globalsecurity.org/military/world/war/maluku.htm [11 July 2005].

[5] C. Stephen S. \& Goss, (2010). "Non-state providers, the state, and health in post-conflict fragile states." Development in Practice 20.4-5: 594-602.

[6] S. Wiryono, (2002). Konflik Aceh jalan panjang menuju perdamaian. http://www.kbri-canberra.org.au/s_issues/aceh/articles/articles_ jalanpanjang.htm [19 Mac 2008].

[7] M. Kholifan, (1999). Babak baru perlawanan orang Papua. Jayapura: Foker LSM.

[8] J.M. Wilson, Rathmell, A., \& Riley, K. J. (2005). Establishing law and order after conflict. Rand Corporation.

[9] CARDI-Maluku. Brief Background. (2005). http://www. internaldisplacement.org/8025708F004CE90B/(httpDocuments)/9 9AFD79F06C8C3F0C12571 A0004E739C/\$file/CARDI-MalukuBrief+Background-Dec2005.pdf [14 Mei 2008].

[10] S. Alhadar, (2000). The forgotten war in North Maluku. Inside Indonesia, July-September.

[11] T. Dodd, (2000). Thousands slain as fabled isles become hell's gates. Australian Financial Review, 12 Januari.

[12] Hasrullah (2009). Dendam Konflik Poso Periode 1998-2001: Konflik Poso dari Perspektif Komunikasi Politik. Jakarta, Gramedia Pustaka Utama.

[13] B.P. Kontras \& catatan monitoring Kontras, S. (2007). Praktek Hukuman Mati di Indonesia.

[14] K. Huber, (2004). The HDC in Aceh: promises and pitfalls of NGO mediation and implementation. Policy Studies (9). Washington: EastWest Center. 
[15] J.M. Wilson, Rathmell, A., \& Riley, K.J. (2005). Establishing law and order after conflict. Rand Corporation.

[16] H. Crouch, (2000). Indonesia's military: backbone of the nation or achilles heel?. Washington: USINDO.

[17] Kontras. (2000). Penyelesaian Konflik Antaragama Melalui Hubungan Pribadi, http://kontras.org/index.php?hal=dalam_berita\&id $=446$

[18] G. Swisher \& Suaib. (2004). Local Economic Development Assessment, Kabupaten Poso, Central Sulawesi: Thematic assessment. Jakarta: UNDP.

[19] Bakornas. (2003). Government of Indonesia. Follow up workshop on the management of IDPs in Indonesia. Sukabumi, 19-20 July.

[20] Human Security Report (2005). War and peace in the 21 ${ }^{\text {st }}$ century. New York: Oxford University Press.

[21] Irin News, Lilianne Fan, (2014), Aceh's unfinished recovery, http:// www.irinnews.org/report/100972/aceh-s-unfinished-recovery

[22] Tempo. (2004). Presiden dan DPR Bertemu Selesaikan Konflik, http:// www.tempo.co/read/news/2004/11/02/05550306/Presiden-dan-DPRBertemu-Selesaikan-Konflik

[23] News Detik.com, 14 ${ }^{\text {th }}$ Jan 2014, http://news.detik.com/ $\mathrm{read} / 2004 / 01 / 14 /$.

[24] A. Sangaji, (2000). Beberapa catatan mengenai kerusuhan di Poso. Disampaikan pada pertemuan mitra NOVIB. Jakarta, 26 July.

[25] F. Alihar, (2012). Transmigrants and Aceh Conflict Trauma. Jurnal KetransmigrasianVol. 29 No. 2 December 2012. 69-78.

[26] D. Burdock, (2006). Kesepakatan baru untuk mengakhiri konflik membawa kepercayaan dan optimisme yang tak terduga. http://www. aceh-eye.org/data_files/bahasa_format/analysis_bhs/analysis_insideind/ analysis_insideind_2006/analysis_insideind_2006_04_06_01.asp [14 January 2008]. 